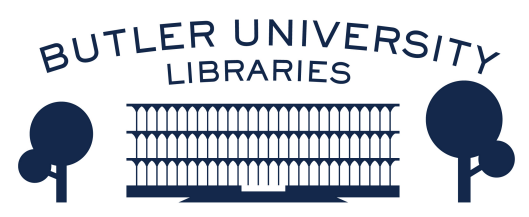

Journal of Hindu-Christian Studies

Volume 18

Article 17

January 2005

\title{
Book Review: "Playing Host to Deity: Festival Religion in the South Indian Tradition"
}

Corinne Dempsey

Follow this and additional works at: https://digitalcommons.butler.edu/jhcs

Part of the Religion Commons

\section{Recommended Citation}

Dempsey, Corinne (2005) "Book Review: "Playing Host to Deity: Festival Religion in the South Indian Tradition"," Journal of Hindu-Christian Studies: Vol. 18, Article 17.

Available at: https://doi.org/10.7825/2164-6279.1350

The Journal of Hindu-Christian Studies is a publication of the Society for Hindu-Christian Studies. The digital version is made available by Digital Commons @ Butler University. For questions about the Journal or the Society, please contact cbauman@butler.edu. For more information about Digital Commons @ Butler University, please contact digitalscholarship@butler.edu. 
conversion views and verifying Hindutva suspicions that Christianity and imperialism are inextricable, evangelization 2000 efforts were countered by Hindu shuddhi reconversion ceremonies. Kim presents the writings of Arun Shourie as thoughtfully representative of Hindu nationalist views and notes that although he may have unfairly criticized diversity within Christianity as a sign of weakness - in comparison with Hinduism he contrived as united - Shourie offered an opportunity for honest debate that Christians missed. Not only did they bypass a chance to learn from an esteemed journalist, they failed to convince Shourie and others of Christianity's new humility. Without acknowledging Shourie's theological reservations, Christians responded to the connections he drew between Christianity and imperialism. Attempting to deny links between Christianity and empire, respondents disingenuously drove a false wedge between the past and present.

Kim's discussion of the debate initiated by Sangh Parivar in the 1990s chronicles a more dramatic and ironic crossfire of blame between and among religious communities. The Parivar's critique of Christianity as intolerant emerged amid their own acts of anti-Christian violence, their rejection of Christianity's universalism amid a campaign for an allIndia Hindutva. Mainline Catholic and Protestant embarrassment regarding evangelical Christian ideology led them to label evangelical groups "fringe" yet such dismissals were unconvincing. Even among mainline denominations, poor parishioners often feel differently about conversion than their middle class pastors; official Vatican statements such as Ecclesia in Asia promote a view of conversion very different from that of its progressive theologians.

Kim's book captures well the complexity of conversion debates from an impressive array of angles. Most impressive, however, is how he manages to remain terrifically even-handed in his treatment of what is often an emotional minefield. He concludes his book by proposing a Christian theology of conversion developed through open scrutiny by non-Christians. He suggests Christians assess the entanglement of foreign missionaries as well as the processes of colonialism, post-colonialism, and globalization yet take into account converts' testimonies of transformation. While both Hindus and Christians must consider the limitations of tolerance within their respective traditions, Kim asks that Christians work from the Golden Rule, offering the same respect for Hindu faith and identity that they would wish in return. In other words, Christian evangelism would be justified only to the extent that Christians would be willing to listen to and learn from Hindus.

Corinne Dempsey

University of Wisconsin at Stevens Point

\section{Playing Host to Deity: Festival Religion in the South Indian Tradition. Paul Younger. New York: Oxford University Press, 2002, vi +189 pp.}

IT never occurred to me that, given a chance, South Indian festivals had so many stories to tell. It does not surprise me, however, that Paul Younger, consummate yarn spinner with decades of experience chronicling South Indian history and ethnography, would be the one to give voice to these multi-registered events. In Playing Host to Deity, Younger deftly guides the reader through the variegated histories, mythologies, political vagaries, and practices of fourteen south Indian religious 
festivals occurring - no less - in. five different countries. The ethnographical, historical, and geographical breadth of this volume might seem better suited for a team rather than an individual - for an edited volume rather than a monograph - yet Younger's single-handed production is a resounding success, one that utilizes well his talents and experience, not to mention his impressive travel record. The volume also provides a reassuring cohesiveness difficult to execute through a multi-authored work.

Playing Host to Deity is comprised of three sections focusing on festivals that manifest, or whose members emphasize, ancient, medieval, and modern patterns, respectively. By illuminating these broad temporal categories, Younger finds the best foothold for comprehending and describing festival practices and community dynamics both past and present.

In his first section, "Ancient Patterns," Younger takes us to the Sabarimalai pilgrimage-festival in Kerala, to Kataragama in southeastern Sri Lanka, to the Kodungalur festival in Kerala, and to Srirankam in Tamil Nadu. Of particular interest to readers of this journal will be the Sabarimalai festival, a site of significant interreligious exchange. Sabarimalai has grown dramatically over the past fifty years, making it one of the largest pilgrimage-festivals in the world. Younger speculates that this has much to do with many South Indians' current interest in Dravidian, pre-Brahmanical culture. Its arduous, back-to-nature pilgrimage seems to provide members of today's educated classes and technological elite - Muslim, Christian, and Hindu - a sense of reconnection with their ancient roots. The Kataragama festival, organized today by Sinhalese Buddhists, involves Hindu and Muslim shrines and practitioners as well as ancient practices associated with the indigenous Vedda community of Sri Lanka. Younger notes that, contrasted with the Sabarimalai festival in which ancient practices have been folded into a Hindu framework without incident, Hindu and Buddhist leaders at Kataragama vie for the supremacy of their respective interpretations of the festival. Meanwhile, the Vedda religious leaders - highly marginalized by normative society - unobtrusively hold forth by anchoring the event in their ancient practices.

The book's second section, "Medieval Structures," covers festivals formed during the emergence of new centers of civilization beginning in the third through the ninth centuries, prompted by developments in irrigation and agriculture, extending until fourteenth-century Muslim invasions. Characterizing these festivals were (and often still are) elaborate political and religious ceremonies funded by powerful landlords. Featured in this section are festivals at two Hindu temples from the Kaveri river valley region in Tamil Nadu (Tiruvanaikka and Srirankam), at the Samayapuram Mariyamman temple in central Tamil Nadu, and at the Kandy temple that houses Buddha's tooth relic in central Sri Lanka. Of interest to scholars of inter-religious exchange will likely be the history, current practices, and politics of the Kandy festival that Younger portrays as wrapped in layers of Hindu/Buddhist syncretism and competition. This section's examples demonstrate how the interests of past and present kings, landlords, and priests manipulate yet never completely overrun ritual practices that reflect and respond to the everyday concerns of devotees.

The final section, "Modern Forms," considers an array of festival types. Three take place outside South Asia (in Guyana, South Africa, and Toronto) and two of the three located in South India are Christian in origin. These festivals are somewhat different from earlier examples in that a sole individual, group, or institution organizes the event. This does not, however, mitigate the kinds of intercommunity interchange and competition seen earlier. For example, Younger details the ways lay-inspired heterodox practices at Christian festivals - at the Velankanni Marian shrine in Tamil Nadu and at a Jacobite Orthodox Church in Kerala also dedicated to Mary - consistently derail clergy's efforts to guide them toward a preferred orthodoxy. Examples of this 
tension between laity and clergy, articulated through festival practices and prescriptions, emerge throughout this book at nonChristian sites, as well.

In the diaspora context, Younger discusses how lay community members commonly adopt a concern for orthopraxy conventionally reserved for priests, offering a means for immigrants and their descendents to retain their roots and/or regain stability as minority members of a society. Younger moreover notes an ironic flexibility amid inflexibility within the community. On one hand, diaspora celebrations are often optional - people seem to understand if logistics make certain practices impossible. Yet, as Younger puts it, "the zeal for the faithful performance of the festival as remembered by the participants becomes a much more central factor than it would be in South India or Sri Lanka, and innovation for its own sake is clearly discouraged" (159).

In almost all instances, Playing Host to Deity demonstrates how "tradition" (contrived or true) strains against forces of entropy and innovation within the festival context. Festivals seem to offer an ideal nexus from which to view complex affiliations within participant communities and the clashing and co-mingling of deeply held desires and concerns. Younger typically allows each multi-vocal festival to speak for itself rather than providing this model of dialogue as an organizing frame; yet, in his concluding remarks about a Siva festival in
Toronto, he does equate South Indian festivals with inter-communal expression and conflict. He describes the Toronto temple community - lay and priestly, Sri Lankan and South Indian Tamil - as being enmeshed in a typical array of diaspora "debates" regarding politics, ethnicity, minority group status, aesthetics, theology, and purity of tradition. The Toronto festival, as he understands it, can only "work" when it provides a context for genuine dialogue: "Whether the [Toronto] festival will serve to contribute to those debates or act as a forum in which a few hundred people can postpone hearing those debates is a question only time will answer. If it does not contribute to those debates, it will not be a true "festival" as South India and Sri Lanka have known that phenomenon over the centuries" (158).

Superficially speaking, festivals are all about pageantry and pomp. Yet in Younger's intricate investigation we find glitz and glamour upstaged by far more urgent and wide-ranging performances. I highly recommend Playing Host to Deity to scholars and students (of all levels) interested in exploring intersections between religious traditions and between ritual, folklore, history, and politics in South Asia and beyond.

Corinne Dempsey

University of Wisconsin at Stevens

Point

\section{Divine Mother, Blessed Mother: Hindu Goddesses and the Virgin Mary. Francis X. Clooney, S.J. New York: Oxford University Press, $2005, x i v+264 p p$.}

\begin{abstract}
DIVINE Mother, Blessed Mother is dazzling, one of the most rewarding books I have read in a long time. It offers several felicitous combinations: three Hindu goddesses and three visions of Mary; a methodological mix of textual reading, theological comparison, and personal
\end{abstract}

invitation; and a collection of texts and commentaries in Sanskrit, Tamil, Latin and Greek, all of which Clooney has beautifully translated for the first time or afresh. Arising out of what he feels to be a twentyfirst century need for Christians to reconsider gender and the divine in light of 